\title{
Removal of Lead(II) from Wastewater Using Stishovite Clay
}

\author{
V. T. PRIYA ${ }^{1 *}$ and V. VENKATESWARAN ${ }^{2}$ \\ ${ }^{1}$ Research and Development Centre, Bharathiyar University, Coimbatore,Tamilnadu, India \\ ${ }^{2}$ Sree Saraswathi Thyagaraja College, Pollachi, Tamilnadu, India \\ drspriya2010@gmail.com
}

Received 18 October 2015 / Accepted 28 October 2015

\begin{abstract}
Systematic batch mode studies on adsorption of $\mathrm{Pb}$ (II) onto Stishovite clay were carried out as a function of parameters like initial metal concentration, contact time, $\mathrm{pH}$ and temperature. The Langmuir and Freundlich adsorption models were applied and the equilibrium data fitted well with both isotherms. The pseudo-second-order kinetic, Elovich, intraparticle diffusion models were tested for the kinetic study. The final results showed that the adsorption process under study could be best described by the pseudo second order equation. Intra particle diffusion studies showed mainly boundary layer effect. Thermodynamic parameters revealed that the adsorption to be spontaneous and endothermic.
\end{abstract}

Keywords: Stishovite clay, Kinetics, Adsorption isotherm, Thermodynamics of adsorption

\section{Introduction}

Lead, one among the heavy metals, is one of the most dangerous contaminant released into the natural waters from various industries such as mining and melting ferrous ores, oil refining, municipal wastes, paint and pigment production and battery manufacturing ${ }^{1}$. When it enters the human body through inhalation or dermal contact, it tends to accumulate in living tissues such as bone, brain, kidney and muscles leading to diseases such as anemia, nephropathy, blood and brain disorders and ultimately even cause death ${ }^{2-3}$.

In recent decades, various techniques including chemical coagulation, adsorption, reverse osmosis, electrolysis, ion exchange and membrane seperation ${ }^{4}$ etc., have been used for reducing the levels of heavy metals in wastewaters. Among these, adsorption technique is mostly preferred for the removal of heavy metals ${ }^{5-7}$ because of economic viability, ease of operation and simplicity of the designing. Commercial activated carbon was most widely used as adsorbent. However its high cost and regeneration problems restricted its use. As a result several low-cost adsorptions have been developed by many a researchers all over the globe for the removal of heavy metals from waste waters from the stand point of ecofriendly, effectiveness and economic considerations. Non-conventional adsorbents developed 
include clay materials such as kaolinite ${ }^{8}$, illite $^{9}$, sepiolite ${ }^{10}$, montmorillionite ${ }^{11}$, siderite, fugirite, magnetite ${ }^{12}$, rectorite $^{13}$ and vermiculite etc. Clay minerals had high sorption, ionexchange and expansion properties. They were widely used to adsorb all kind of pollutants from large volume of aqueous solutions. The objective of the present study was to explore the feasibility of the removing of $\mathrm{Pb}$ (II) from waste waters using Stishovite clay as an adsorbent.

\section{Experimental}

A stock solution of (1000 mg/L) lead(II) was prepared by dissolving $1.5985 \mathrm{~g}$ of anhydrous lead nitrate in $1000 \mathrm{~mL}$ of doubly distilled water.

\section{Determination of lead ${ }^{14}$}

Lead(II) was estimated spectrophotometrically using PAR reagent (4-(2-pyridylazo) resorcinol mono sodium salt). A suitable aliquot of the sample containing not more than $50 \mu \mathrm{g}$ of lead(II) was transferred into a $25 \mathrm{~mL}$ volumetric flask. $10 \mathrm{~mL}$ of ammoniaammonium chloride buffer solution $\left(33.8 \mathrm{~g} \mathrm{NH}_{4} \mathrm{Cl}+286 \mathrm{~mL}\right.$ of liquid ammonia made up to $500 \mathrm{~mL}$ with distilled water) was added to maintain a $\mathrm{pH}$ of 10.0 followed by $1 \mathrm{~mL}$ of $0.01 \%$ solution of PAR reagent. The solution was made up to the mark with distilled water. The absorbance was measured at $520 \mathrm{~nm}$ against blank. A calibration graph for (5-50 $\mu \mathrm{g}$ of $\mathrm{Pb}$ ) was prepared by adapting the above procedure and the concentration of lead(II) in the sample aliquot was calculated by referring the calibration graph.

\section{Characterization of adsorbent}

Physicochemical characteristics of the adsorbents were studied as per the standard testing methods. The XRD pattern of Stishovite clay (Figure 1) showed characteristic peaks at $30^{\circ}$ confirming the presence of Stishovite phase in the clay. The surface morphology of the adsorbents was visualized via scanning electron microscopy (SEM) (Figure 2). The diameter of the clay range was $100 \mu \mathrm{m}$.

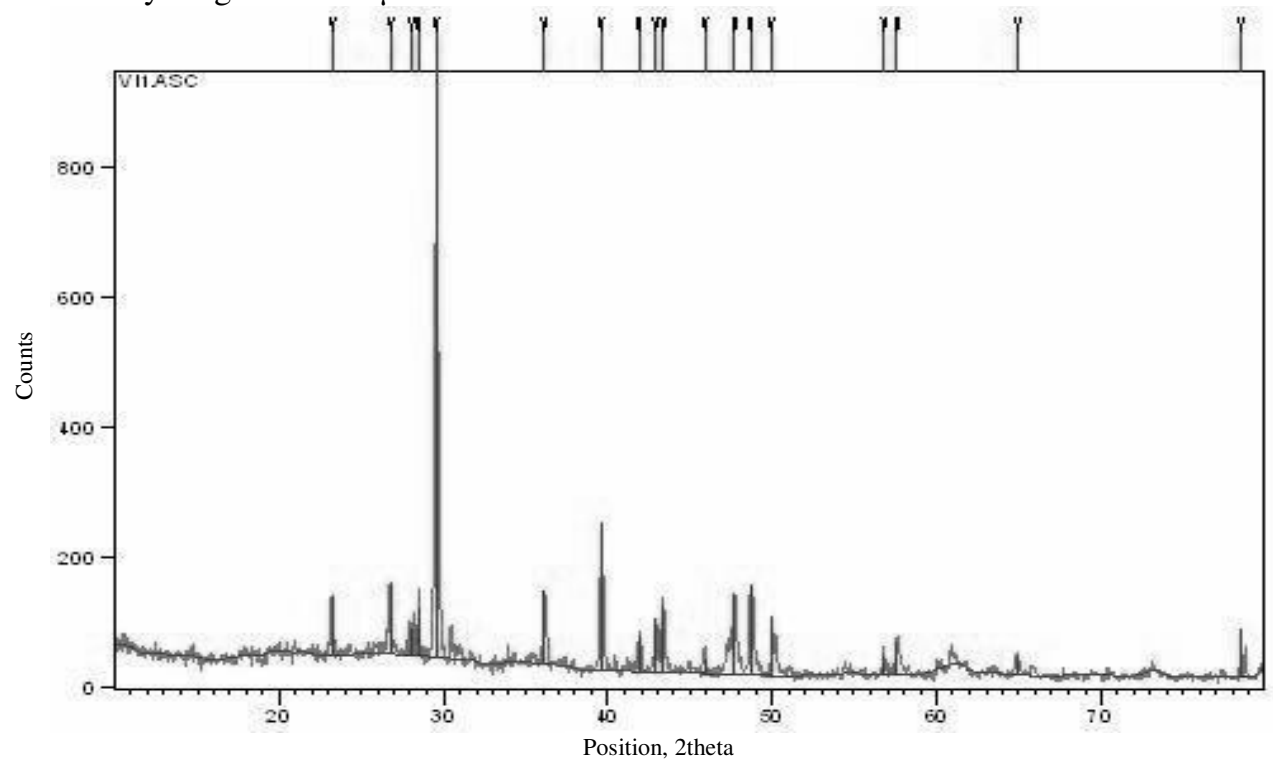

Figure 1. XRD analysis of Stishovite 


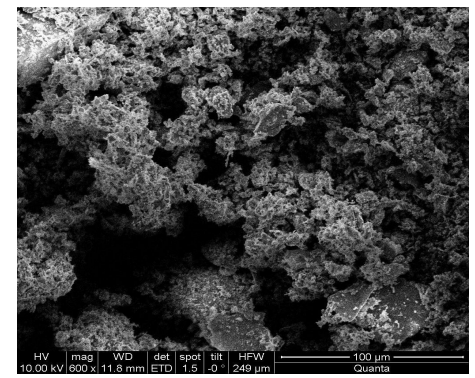

Figure 2. SEM of Stishovite

\section{Batch adsorption experiments}

Entire batch mode experiments were carried out by taking $50 \mathrm{~mL}$ of the metal solution and a known amount of the adsorbent in a $100 \mathrm{~mL}$ conical flask. The flasks were agitated for predetermined time intervals in a thermostat attached with a shaker at the desired temperatures ( $301 \mathrm{~K}$ to $317 \mathrm{~K}$ ) and then the adsorbent and adsorbate were separated by filtration. Studies on the effects of agitation time, $\mathrm{pH}$, initial metal concentration, adsorbent dose and temperature were carried out by using known amount of adsorbent and $50 \mathrm{~mL}$ of metal solution of different concentrations. Metal solution $(50 \mathrm{~mL})$ with different amounts of adsorbent was taken to study the effect of adsorbent dosage.

\section{Results and Discussion}

\section{Effect of contact time and initial metal concentration}

The experimental results of adsorptions at various initial metal concentrations (10, 20, 30 and $40 \mathrm{mg} / \mathrm{L}$ ) on clay was shown in Figure 3. It was observed that the percentage removal at equilibrium increases from $56.94 \%$ to $85.24 \%$ as the initial metal concentration was increased from $10 \mathrm{mg} / \mathrm{L}$ to $40 \mathrm{mg} / \mathrm{L}$. At lower concentrations, the ratio of the initial number of metal ions to the available surface area is low. Subsequently, the fractional adsorption becomes independent of initial concentration.

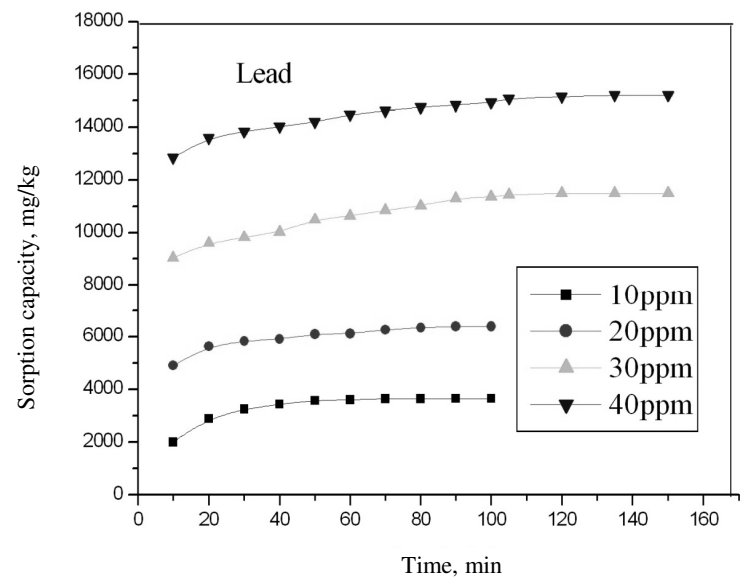

Figure 3. Effect of initial metal concentration

However, at higher concentrations the available sites of adsorption become fewer and hence the percentage removal of metal becomes dependent upon initial concentration ${ }^{9-10}$. 
The equilibrium was found to get established at 40, 50, 75 and $105 \mathrm{~min}$ for lead with the adsorbent as the initial metal concentration was increased from $10 \mathrm{mg} / \mathrm{L}$ to $40 \mathrm{mg} / \mathrm{L}$. The curves are single, smooth and continuous, leading to saturation, suggesting the possible monolayer coverage of the metal on the adsorbent surfaces ${ }^{15}$.

\section{Effect of adsorbent dose}

The adsorption of the $\mathrm{Pb}(\mathrm{II})$ was studied by varying the adsorbent dose $(100-1000 \mathrm{mg} / 50 \mathrm{~mL})$ for 10 to $40 \mathrm{mg} / \mathrm{L}$ initial metal concentrations. The percentage of adsorption increased with increase in amount of the adsorbent (Figure 4). This was attributed to increase in surface area and the availability of more adsorption sites ${ }^{16-17}$ with increase in the adsorbent dose.

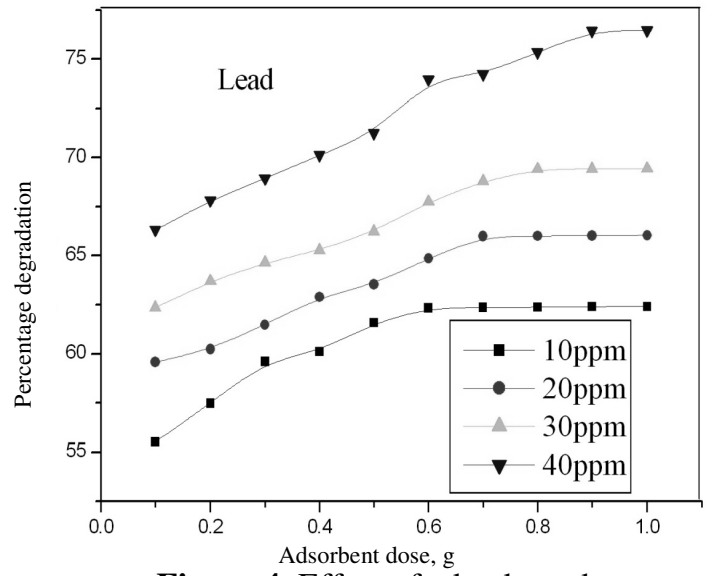

Figure 4. Effect of adsorbent dosage

\section{Effect of $p H$}

Adsorption experiments were carried out at various $\mathrm{pH}$ values ranging from 5 to 11 , maintaining the $\mathrm{pH}$ by adding required amount of dilute hydrochloric acid and sodium hydroxide solutions. The sorption capacity increased with increase in $\mathrm{pH}$. Figure 5 indicates that maximum metal removal had occurred in basic medium.

\section{Effect of temperature}

The effect of temperature on the removal of $\mathrm{Pb}$ (II) by Sovitetish clay was shown in Figure 6 . The amount of metal adsorbed increased with increasing temperature from $301 \mathrm{~K}$ to $317 \mathrm{~K}$ indicating the adsorption process to be endothermic. This may be due to the increase in the rate of diffusion of adsorbate molecules across the external boundary layer and internal pores of adsorbent with increase in temperature.

\section{Adsorption isotherms}

The experimental data were fit into Langmuir and Freundlich isotherms

\section{Langmuir isotherm}

In linear form the Langmuir model ${ }^{18}$ is usually expressed as,

$$
\frac{C_{e}}{q_{e}}=\frac{1}{b Q^{0}}+\frac{C_{e}}{Q^{0}}
$$

Where $\mathrm{C}_{\mathrm{e}}$ is equilibrium concentration of metal (mg/L), $\mathrm{q}_{\mathrm{e}}$ is the amount of metal adsorbed at equilibrium (mg/g), ' $\mathrm{Q}$ ' and ' $\mathrm{b}$ ' are the Langmuir constants correlated to adsorption capacity and rate of adsorption respectively. A linear plot of $\mathrm{C}_{\mathrm{e}} / \mathrm{q}_{\mathrm{e}} v s$. Ce is shown in Figure 7. 


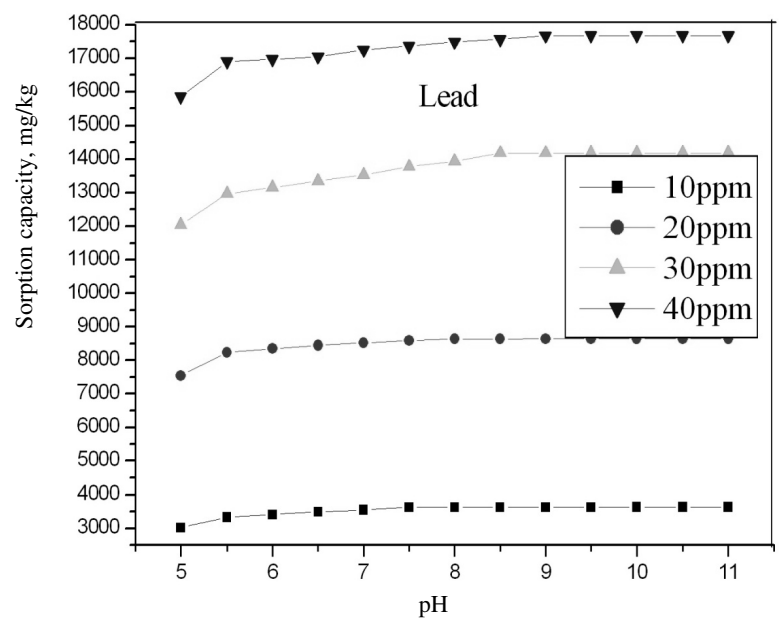

Figure 5. Effect of $\mathrm{pH}$

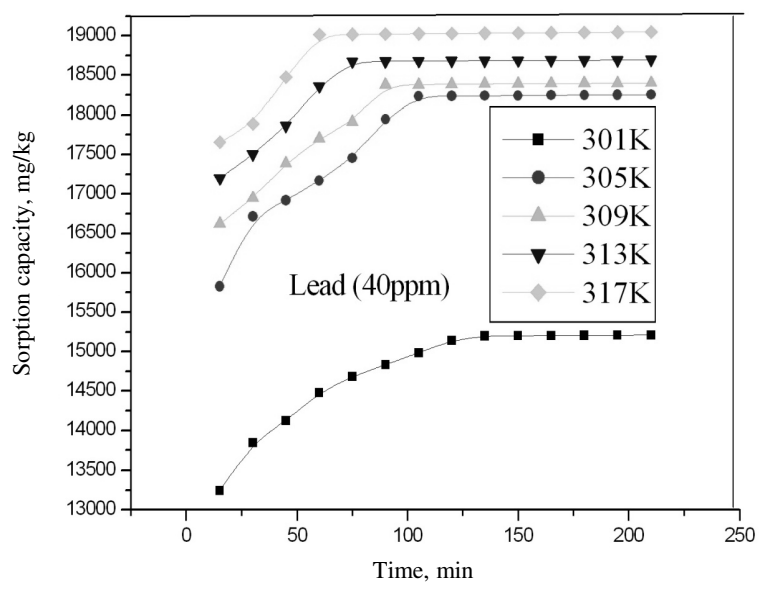

Figure 6. Effect of temperature

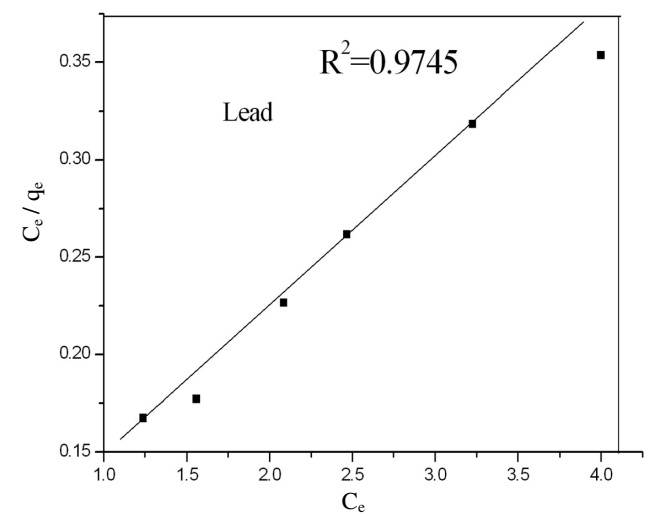

Figure 7. Langmuir isotherm 
The values of $\mathrm{Q}^{0}$ and $\mathrm{b}$ were calculated from the slope and intercept of the plots and the values are given in Table 1 . These values indicate that the maximum monolayer adsorption capacity of Stishovite clay for $\mathrm{Pb}(\mathrm{II})$ was $21.09 \mathrm{mg} / \mathrm{g}$. The crucial features of the Langmuir isotherm was examined by the dimensionless constant separation term $\left(\mathrm{R}_{\mathrm{L}}\right)$ which was calculated using

$$
R_{L}=\frac{1}{\left(1=b C_{0}\right)}
$$

Where $\mathrm{C}_{0}$ is initial metal concentration $(\mathrm{mg} / \mathrm{L})$. The nature of adsorption is if, $\mathrm{R}_{\mathrm{L}}>1$ Unfavourable, $\mathrm{R}_{\mathrm{L}}=1$ Linear, $\mathrm{R}_{\mathrm{L}}=0$ Irreversible, $0<\mathrm{R}_{\mathrm{L}}<1$ Favourable. In the present study, the $\mathrm{R}_{\mathrm{L}}$ values were all less than unity in the concentration range studied, showing that the adsorption process was favourable.

Table 1. Data for Langmuir adsorption isotherm for lead

\begin{tabular}{ccccc}
\hline Conc. of metal, & \multicolumn{4}{c}{ Lead (Stishovite clay) } \\
\cline { 2 - 5 } $\mathrm{mg} / \mathrm{L}$ & $\mathrm{R}_{\mathrm{L}}$ & $\mathrm{b}$ & $\mathrm{Q}^{0}, \mathrm{mg} / \mathrm{g}$ & $\mathrm{R}^{2}$ \\
\hline 20 & 0.181 & & & \\
40 & 0.142 & & & \\
60 & 0.129 & 0.265 & 21.0970 & 0.9745 \\
80 & 0.102 & & & \\
100 & 0.097 & & & \\
120 & 0.0750 & & & \\
\hline
\end{tabular}

\section{Freundlich isotherm ${ }^{19}$}

The Freundlich isotherm can be represented in its logarithmic form as,

$$
\log q_{e}=\log K_{f}+\frac{1}{n} \log C_{e}
$$

Where $\mathrm{K}_{\mathrm{f}}$ and $\mathrm{n}$ are Freundlich constants representing adsorption capacity and intensity of the adsorbent respectively. The plot of $\log \mathrm{q}_{\mathrm{e}} v s . \log \mathrm{C}_{\mathrm{e}}$ shown in Figure 8.

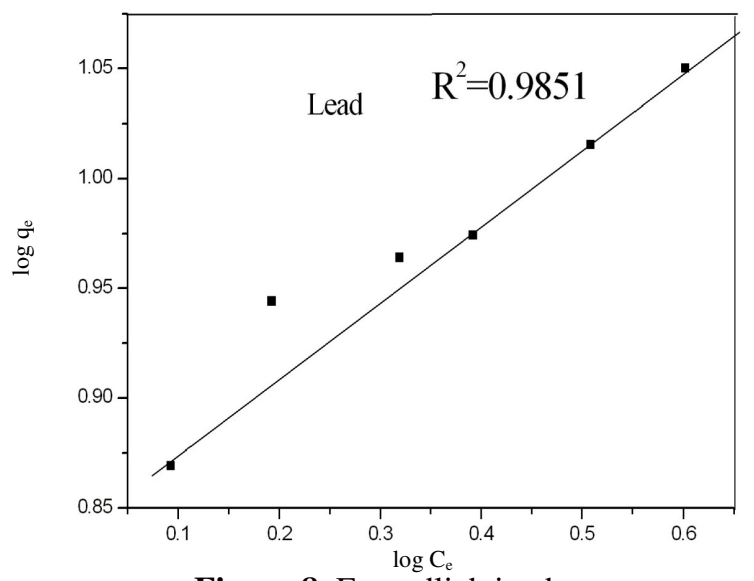

Figure 8. Freundlich isotherm

The linear plot with a regression coefficient of 0.9851 shows that the data for the adsorption of $\mathrm{Pb}$ (II) fit well with Freundlich isotherm. The value of $\mathrm{n}$, evaluated as 1.321 indicates that the process was favorable ${ }^{20}$. The value of $K_{\mathrm{f}}$ was found to be $8.091\left[\mathrm{mg}^{1-1 / n} \mathrm{~L}^{1 / n} \mathrm{~g}^{-1}\right]$ respectively. 


\section{Kinetics of adsorption}

In order to investigate the mechanism of adsorption of $\mathrm{Pb}(\mathrm{II})$ by the clay the following kinetic models were considered.

\section{Pseudo second order kinetics}

In the linearised form pseudo second order kinetic model can be represented as

$$
\frac{t}{q_{t}}=\frac{1}{k_{2} q_{e}^{2}}+\frac{1}{q_{e}} t
$$

Where $\mathrm{k}_{2}$ is the second order rate constant $\left(\mathrm{g} \cdot \mathrm{mg}^{-1} \cdot \mathrm{min}\right)$. A plot of $\mathrm{t} / \mathrm{q}_{\mathrm{t}}$ and $\mathrm{t}$ should give a linear relationship if the adsorption follows second order $\mathrm{q}_{\mathrm{e}}$ and $\mathrm{k}_{2}$ can be calculated from the slope and intercept of the plot. The linear plots (Figure 9) obtained from experimental data clearly show that the adsorption process follow pseudo second order kinetics.

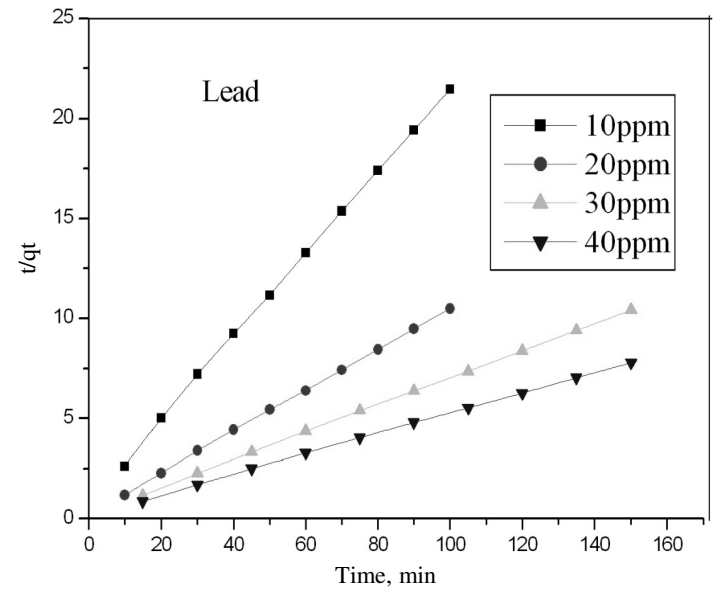

\section{Elovich kinetic model}

Figure 9. Pseudo second order kinetics

The Elovich equation mainly applied for chemisorptions and valid for systems with heterogeneous adsorbing surfaces ${ }^{21}$ is generally expressed in its integrated form as

$$
q_{t}=\frac{1}{b} \ln t+-\frac{1}{b} \ln (a b)
$$

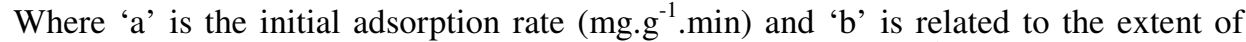
surface coverage and the activation energy for chemisorptions $\left(\mathrm{g}^{\mathrm{m}} \mathrm{mg}^{-1}\right)$. A plot of $\mathrm{q}_{\mathrm{t}} v s$. $\ln \mathrm{t}$ gives a straight line with a slope of $1 / \mathrm{b}$ and an intercept $\log 1 / \mathrm{b} \ln (\mathrm{ab})$ with good correlation coefficients $(0.8977,0.9174,0.9386$ and 0.9586$)$. Figure 10 strongly supports the validity of the Elovich equation suggesting chemisorptions.

\section{Thermodynamic of adsorption}

Thermodynamic parameters like $\Delta H^{0}, \Delta S^{0}$ and $\Delta G^{0}$ were evaluated using the following equations

$$
\begin{gathered}
\ln K c=\Delta S \% / R-\Delta H \% / R \\
\Delta G^{0}=\Delta H^{0}-T \Delta S^{0}
\end{gathered}
$$

Where $\mathrm{K}_{\mathrm{C}}$ is the Langmuir equilibrium constant, $\Delta \mathrm{H}^{0}, \Delta \mathrm{S}^{0}$ and $\Delta \mathrm{G}^{0}$, are the standard enthalpy, entropy and free energy change of adsorption respectively. Negative free energy 
changes $(1.149,1.164,1.179,1.193,1.208 \mathrm{~kJ} / \mathrm{mol}$ at $301 \mathrm{~K}-317 \mathrm{~K})$ and positive entropy change $(3.7155 \mathrm{~kJ} / \mathrm{mol})$ of adsorption indicate that the adsorption is favorable and spontaneous process. The endothermic nature of adsorption is confirmed by the positive value of $\Delta \mathrm{H}^{0}(30.9629 \mathrm{~kJ} / \mathrm{mol})$.

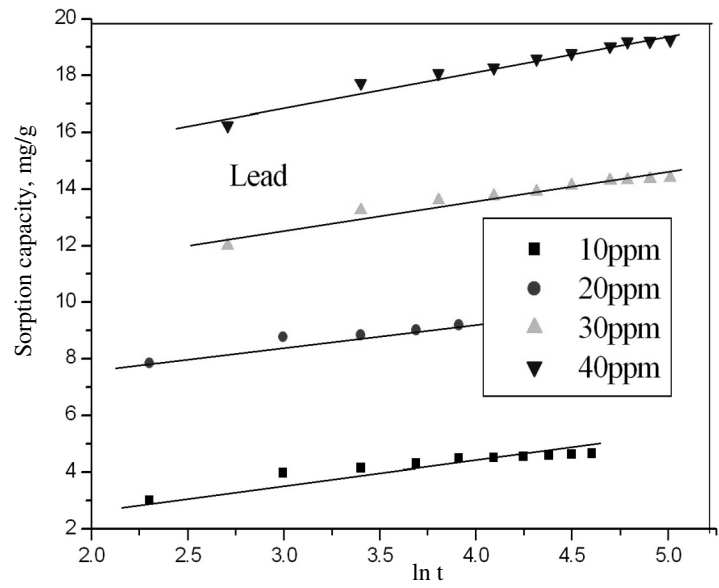

\section{Desorption studies}

Figure 10. Elovich kinetic model

Desorption studies with acetic acid revealed that the regeneration of adsorbent was not satisfactory, which confirms the chemisorptive nature of adsorption.

\section{Conclusion}

The present investigation showed that Stishovite clay can be used as an effective adsorbent for removal of lead(II). The amount of metal adsorbed varied with initial metal concentration, adsorbent dose, $\mathrm{pH}$ and temperature. Removal of metal by Stishovite clay obeyed both Langmuir and Freundlich isotherms. The adsorption process followed pseudo second order kinetics.

\section{References}

1. Axtell N R, Sternberg S P K and laussen K, Bioresource Technol., 2003, 89(1), 41-48; DOI:10.1016/S0960-8524(03)00034-8

2. Kazi T G, Jalbani N, Jamali M K, Arain M B, Afridi H I, Kandhro A and Pirzado Z, Renal Failure, 2008, 30(7), 737-745; DOI:10.1080/08860220802212999

3. Afridi H I, Kazi T G, Jamali G H and Shar G Q, Biol Trace Elem Res., 2006, 113(1), 19-34; DOI:10.1385/BTER:113:3

4. Chen H, Zhao J, Dai G L, Wu J Y and Yan H, Desalination, 2010, 262(1-3), 174-182; DOI:10.1016/j.desal.2010.06.006

5. Mudhoo A, Garg V K and Wang S B, Environ Chem Lett., 2011, DOI:10.1007/s 10311-011-0342-2

6. Kul A R, and Koyuncu H, J Hazard Mater., 2010, 179(1-3), 332-339; DOI:10.1016/j.jhazmat.2010.03.009

7. Astier C, Chaleix V, Faugeron C, Ropartz D, Krausz P and Gloaguen V, BioResources., 2012, 7(1), 1100-1110.

8. Srivastava S K, Tyagi R, Pant N and Pal N, Environ Technol., (Letters), 1989, 10(3), 275-282; DOI:10.1080/09593338909384742 
9. Echeverria J C, Zarranz I, Estella J and Garrido J J, Appl Clay Sci., 2005, 30(2), 103115; DOI:10.1016/j.clay.2005.03.006

10. Brigatti M F, Lugli C and Poppi L, Appl Clay Sci., 2000, 16(1-2), 45-57; DOI:10.1016/S0169-1317(99)00046-0

11. Abollino O, Aceto M, Malandrino M, Sarzanini C and Mentasti E, Water Res., 2003, 37(7), 1619-1627; DOI:10.1016/S0043-1354(02)00524-9

12. Johnson J and Sherman D H, Chem Geol., 2008, 255(1-2), 173-181; DOI:10.1016/j.chemgeo.2008.06.036

13. Zili Liu, Feng Peng and Xiaoguo Liu, Adv Mater Res., 2012, 550-553, 2428-2435.

14. Pollard F H, Hanson P and Geary W J, Anal Chim Acta, 1959, 20, 26-31; DOI:10.1016/0003-2670(59)80004-0

15. Arivoli S, Environ Sci Ind J., 2007, 2, 167.

16. Namasivayam C, Muniasamy N, Gayathri K, Rani M and Renganathan K, Biores Technol., 1996, 57(1), 37-43; DOI:10.1016/0960-8524(96)00044-2

17. Namasivayam C and Yamuna R T, Environ Pollut., 1995, 89(1), 1-7; DOI:10.1016/0269-7491(94)00056-J

18. Langmuir I, J Am Chem Soc., 1916, 38(11), 2221-2295; DOI:10.1021/ja02268a002

19. Freundlich H, Phys Chemie., 1906, 57, 384-470.

20. Bell T R K, Mass Transfer Operations, $10^{\text {th }} E d$., McGraw-Hill, New York, 1998.

21. Low M J D, Chem Rev., 1960, 60(3), 267-312; DOI:10.1021/cr60205a003 